\title{
ANALYSIS AND COMPARATION OF LEGISLATION AND ACCOUNTING OF FOUNDATIONS AND ENDOWMENT FUNDS IN THE CZECH REPUBLIC IN YEARS 1989 TO 2014
}

\author{
[Analýza a komparace právní úpravy a účetnictví nadací a nadačních fondů \\ v České republice v letech 1989 až 2014] \\ Alžběta Urbancová ${ }^{1}$, Šárka Kryšková $^{2}$ \\ ${ }^{1}$ Vysoká škola báňská - Technická univerzita Ostrava, Ekonomická fakulta, Sokolská trída 33, 70121 Ostrava \\ Email:alzbeta.urbancova@vsb.cz. \\ ${ }^{2}$ Vysoká škola báňská - Technická univerzita Ostrava, Ekonomická fakulta, Sokolská tř́da 33, 70121 Ostrava \\ Email: sarka.kryskova@vsb.cz
}

\begin{abstract}
The aim of this paper is to describe, analyze and compare the development of conditions for the activities of foundations and endowment funds in the Czech Republic in the area of legislation and accounting in years 1989 to 2014. The analysis is focused on:

- the development of the legal regulations of foundations and endowment funds after 1989, after the effect of a separate law on foundations and endowment funds up to the present, which is related to the adoption of the new Civil Code,

- changing conditions for accounting, financial statements, the content and the publication of annual reports and their verification by the auditor.

The integral part of this paper is to draw attention to the negative aspects of the changes, suggest possible measures to address the drawbacks and facilitate the decision-making process of potential founders whether or not to establish a foundation or endowment fund while respecting legal and accounting perspective.
\end{abstract}

Keywords: accounting, annual report, audit of financial statements, endowment fund, foundation, legal regulation, public benefit entities, status of public benefit.

JEL classification: L31, M41, M42

Doručeno redakci: 23.2.2014; Recenzováno: 15.5.2014; 16.5.2014; Schváleno k publikování: 23.9.2014

\section{Úvod}

Cílem příspěvku je provést analýzu vývoje právní úpravy a měnících se podmínek pro vedení účetnictví, sestavování účetní závěrky, výročních zpráv a jejich ověřování auditorem v jednotlivých etapách vývoje nadací a nadačních fondů v České republice po roce 1989. Cílem príspěvku je také porovnat podmínky pro činnost těchto právnických osob s podmínkami, které budou platit po 1. 1. $2014 \mathrm{v}$ souvislosti s účinností nového občanského zákoníku (dále NOZ, zákon č. 89/2012 Sb., občanský zákoník). Nedílnou součástí cíle je upozornit na negativa provedených změn a navrhnout možná opatření k řešení úskalí a konfliktů souvisejících s účinností nového občanského zákoníku. Přínosem tohoto příspěvku by mělo být usnadnit rozhodování potencionálních zakladatelů při řešení otázky, zda založit nadaci nebo nadační fond při současném respektování právních a účetních souvislostí.

\section{Právní úprava nadací a nadačních fondů}

Činnost nadací a nadačních fondů ovlivňuje život občanů v České republice především v oblasti zdravotnictví, školství, vědy a výzkumu, kultury, ochrany životního prostředí a ochrany zviŕat, ale také v oblasti sociální, humanitární a charitativní. Obecně lze konstatovat, že nestátní neziskové organizace kam nadace a nadační fondy patří, mohou trvale vyvíjet činnost pouze tehdy, jestliže existuje speciální legislativa založená na jasném 
konceptu třetího sektoru jako celku. Nestátní neziskové organizace potřebují zákony, které chrání jejich nezávislost a umožňují dlouhodobou existenci. Přílišná regulace ale může být na překážku rozvoje, nicméně je v zájmu neziskových organizací, aby právní rámec byl dostatečně př́sný a odrazoval, ty kdo by chtěli výhod nestátních neziskových organizací zneužívat. Organizace, které se tváŕí jako občanské iniciativy a které zneužívají právní formy nestátních neziskových organizací, podrývají důvěru společnosti ke třetímu sektoru jako celku. (Hurdík,1994)

Minulá a současná právní úprava upřednostňuje právní formu před obsahem, dle důvodové zprávy $\mathrm{k}$ návrhu zákona o statusu veřejné prospěšnosti je prř́stup upřednostňování právní formy označován za nekoncepční. Nová koncepce právní úpravy nadací a nadačních fondů si kladla za cíl zvýšení transparentnosti a důvěry veřejnosti v jejich činnost. „Ve většině evropských států je veřejně prospěšná činnost určitého subjektu deklarována přiznáním statusu veřejné prospěšnosti, jehož získáni je navázáno na prokázání výkonu určité činnosti, prípadně na následné rozhodnutí určité autority, která status veřejné prospěšnosti přiznává. "

\section{Kritéria pro analýzu a komparaci právní úpravy nadací a nadačních fondů}

Příslušné zákony se musí zabývat všemi etapami života právnické osoby - počínaje způsobem registrace až po její zánik, způsobem zrušení a zániku či likvidace. Způsob registrace by neměl být př́liš nákladným a administrativně náročným procesem, ale jednoduchým, transparentním a stejně dostupným všem členům společnosti. Legislativa by měla jasně definovat podmínky pro zrušení, zánik a pravidla pro nakládání s likvidačním zůstatkem. Nedílnou součástí právní úpravy nadací a nadačních fondů by měla být ustanovení týkající se podmínek pro podnikání, pro poskytování nadačních příspěvků, nákladů na správu a také ustanovení týkající se povinnosti zveřejňování účetní závěrky a výroční zprávy včetně jejich ověření auditorem. Pro potřeby tohoto příspěvku pro analýzu a komparaci právní úpravy byla zvolena zejména tato kritéria: právní úprava (zákon), definice účelu, cíle, poslání, podmínky pro založení a vznik (registrace), podmínky pro zrušení a zánik, likvidační zůstatek, výše jmění (nadační jistina, nadační kapitál), statut, podnikání a účast na podnikání jiných osob, náklady na správu, orgány, podmínky pro poskytování nadačních příspěvků, účetní soustava, rozsah vedení účetnictví, účetní závěrka a audit účetní závěrky, výroční zpráva a způsoby zveřejňování. Vývoj právní úpravy nadací a nadačních fondů lze začlenit do dvou období: minulost (historie) a současnost (přesnější specifikace viz tabulka 1).

Tabulka 1: Vývoj právní úpravy nadací a nadačních fondů

\begin{tabular}{|c|c|c|}
\hline \multicolumn{3}{|c|}{ Období (etapy) života nadací a nadačních fondů } \\
\hline \multicolumn{2}{|c|}{ minulost } & současnost \\
\hline $\begin{array}{c}\text { období před účinností } \\
\text { zákona č. } 227 / 1997 \mathrm{Sb} \text {., } \\
\text { o nadacích a nadačních fondech }\end{array}$ & $\begin{array}{l}\text { období po účinnosti } \\
\text { zákona č. } 227 / 1997 \mathrm{Sb} ., \\
\text { o nadacích a nadačních fondech } \\
\text { do } 31.12 .2013\end{array}$ & $\begin{array}{c}\text { období po účinnosti } \\
\text { zákona č. 89/2012 Sb., občanský } \\
\text { zákoník }\end{array}$ \\
\hline pouze nadace & nadace a nadační fondy & fundace (nadace a nadační fondy) \\
\hline $1989-31.12 .1997$ & $1.1 .1998-31.12 .2013$ & po 1.1 .2014 \\
\hline
\end{tabular}

Zdroj: vlastní zpracování

\subsection{Právní úprava nadací před účinností zákona o nadacích a nadačních fondech}

Jestliže se ohlédneme do historie právní úpravy nadací před rokem 1990 (nadační fondy jsou zřizovány až po 1. 1. 1998), lze konstatovat, že aplikace zákona č. 115/1953 Sb., o právu

\footnotetext{
${ }^{1}$ http://obcanskyzakonik.justice.cz/tinymce-storage/files/zovp.pdf

Důvodová zpráva $k$ vládnímu návrhu zákona o statusu veřejné prospěšnosti
} 
autorském (autorský zákon) měla za následek zrušení a zánik nadací vzniklých před první a druhou světovou válkou. Jedinou soukromoprávní nadací, která u nás nepřetržitě působí od svého založení v roce 1904 je Nadace „Nadání Josefa, Marie a Zdeňky Hlávkových“.2

\section{Nadace podle hospodářského zákoníku}

S účinností od 1. 5. 1990 byl novelizován hospodářský zákoník a do našeho právního řádu se vrací pojem účelový fond (nadace). ${ }^{3}$ Právní úprava nadací byla provedena ustanovením jediného paragrafu (§ 389b). Prostřednictvím tohoto paragrafu byl zakotven právní rámec pro zřizování a působení nadací jako právnických osob. I přes kusost úpravy (pouze 3 odstavce) a určité výhrady (absence výše jmění, náležitostí statutu, odkaz na právní předpis pro občanská sdružení), znamenalo citované ustanovení hospodářského zákoníku zásadní průnikový význam v životě společnosti a odklon od uplatňování autority státu a státních zásahů do činnosti a hospodaření těchto právnických osob. (Telec, 1994)

Na nadace a účelové fondy založené v letech 1990 až 1991 podle hospodářského zákoníku se pak (od 1. 1. 1992) vztahovalo ustanovení § 875 občanského zákoníku v tehdejším znění, podle kterého se již existující (stávající, dosavadní) nadace považují za nadace podle $\S 20 \mathrm{~b}$ až 20e občanského zákoníku.

\section{Nadace podle občanského zákoníku}

Další důležitý mezník ve vývoji legislativy nadací u nás prrímo souvisel s novelou občanského zákoníku a se zrušením hospodářského zákoníku s účinností od 1. ledna 1992. Od tohoto okamžiku až do 1. 1. 1998 (datum účinnosti zákona o nadacích a nadačních fondech) upravoval problematiku nadací zákon č. 40/1964 Sb., občanský zákoník v ustanoveních $\S 20 b$ až 20e, zároveň se na nadace vztahovala i obecná ustanovení $§ 18$ až 20a. Na rozdíl od předchozí úpravy nadací podle obchodního zákoníku, ustanovení občanského zákoníku již obsahují náležitosti statutu, na straně druhé v př́padě likvidace odkazují použít přiměřeně obchodní zákoník.

V grafické podobě vývoj právní úpravy obsahuje obrázek 1 Vývoj právní úpravy nadací nadačních fondů v České republice. ${ }^{4} \mathrm{Z}$ tohoto schématu je zřejmé, že legislativní změny měly vliv i na způsob vzniku (registrace), první nadace měly povinnost se registrovat u okresního národního výboru, nadace založené podle občanského zákoníku měly povinnost se zaregistrovat $u$ př́śslušného státního orgánu (okresního úřadu), nadace a nadační fondy založené po 1. 1. 1998 pak vznikaly dnem zápisu v nadačním rejstř́íku a fundace, jejichž vznik se bude datovat po 1. 1. 2014 se budou zapisovat do veřejného rejstř́ku.

Nadace vzniklé před 1. 1. 1998 měly (mimo jiné) 12 měsíční lhůtu na ukončení své činnosti nebo na transformaci na nadaci nebo nadační fond, na sloučení s jinou nadací nebo na transformaci na obecně prospěšnou společnost. Činnost již existujících nadací a nadačních fondů a vznik fundací po 1. 1. 2014 bude upravovat NOZ. Komparace právní úpravy a podmínek pro činnost nadací i nadačních fondů podle vybraných kritérií uvedených v úvodu je obsažena $\mathrm{v}$ tabulce 2 . V této tabulce je $\mathrm{v}$ přehledné formě uvedeno srovnání legislativy před i po přijetí zákona č. 227/1997 Sb., o nadacích a nadačních fondech.

\footnotetext{
${ }^{2}$ http://www.hlavkovanadace.cz/

${ }^{3}$ zákon č. 103/1990 Sb., kterým se mění a doplňuje hospodářský zákoník (zákon, kterým byl novelizován zákon č. 109/1964 Sb., hospodářský zákoník)

${ }^{4}$ Název schématu je zkrácený, v názvu by pro úplnost mělo být uvedeno v Československé socialistické republice, Československé federativní republice, České a Slovenské Federativní republice a České republice.
} 


\subsection{Právní úprava nadací a nadačních fondů podle zákona o nadacích a nadačních fondech}

V průběhu let 1991 až 1997 bylo vypracováno několik znění samostatného zákona o nadacích, přičemž zpracované varianty předpokládaly zásadní změny oproti existujícímu stavu. V oblasti legislativy bylo vykonáno kus práce, která byla završena přijetím samostatného zákona č. 227/1997 Sb., o nadacích a nadačních fondech.

Obrázek 1: Vývoj právní úpravy nadací a nadačních fondů v České republice
M1. 5. 1990
1. 1.1992
1. 1.1998
31. 12.1998

1. 1.2014

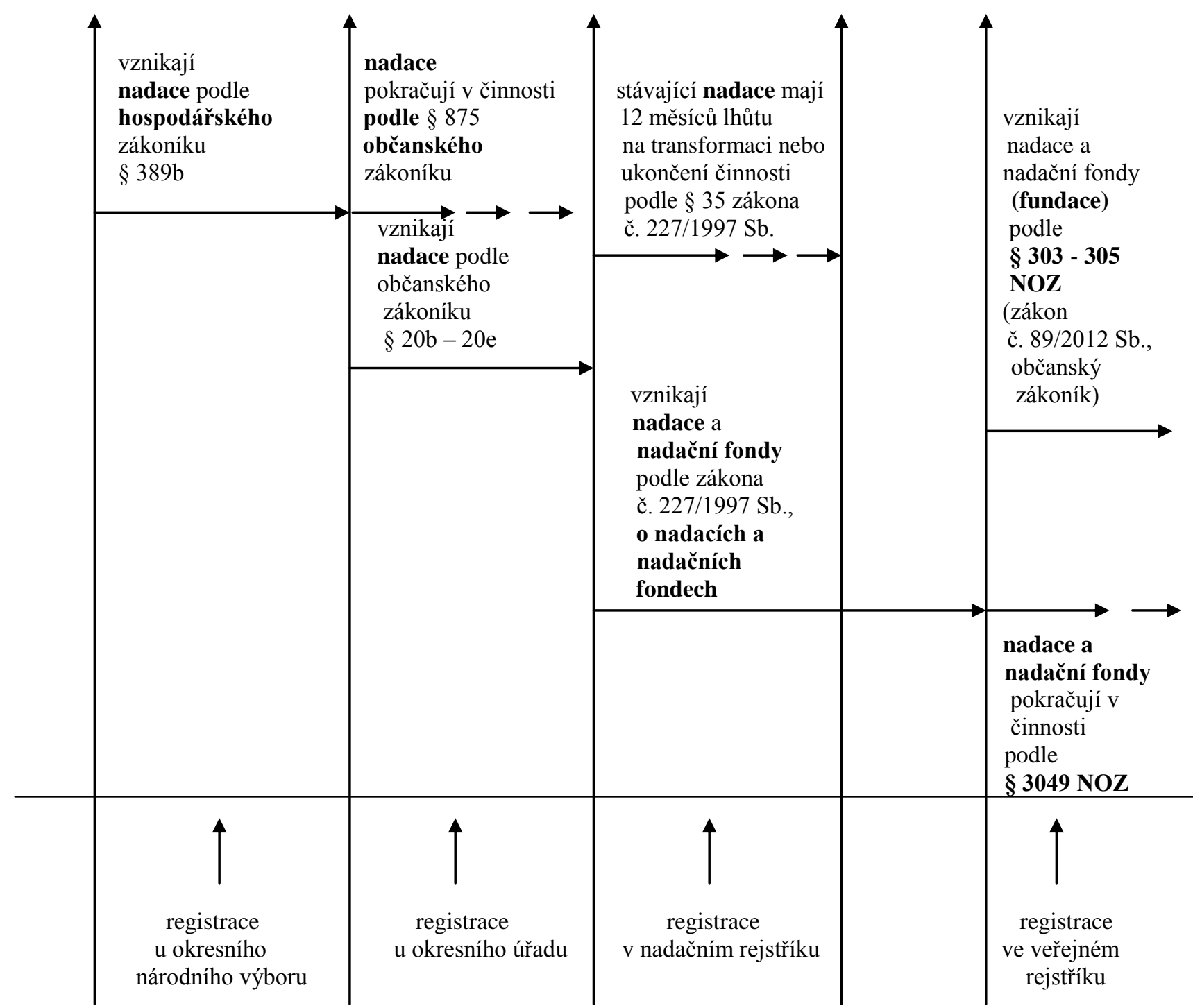

Zdroj: (Urbancová, 2000, Př́loha č. 1), aktualizované vlastní zpracování

Přijetím zákona č. 227/1997 Sb. došlo ke zpř́ísnění podmínek pro činnost nadací a byly nastaveny mantinely pro činnost nadačních fondů a to především:

- definováním obecně prospěšného cíle (došlo k rozšíření o vědu, vzdělání, tělovýchovu a sport),

- registrací u rejstř́kového soudu,

- stanovením minimální hodnoty jmění u nadací,

- zákazem podnikání pro nadace i nadační fondy a vymezením podmínek pro účast nadací na podnikání jiných osob, 
- definováním náležitostí statutu,

- stanovením zásad a pravidel pro poskytování nadačních příspěvků (zákaz podílet se financování politických stran a zákaz poskytovat nadační př́spěvky členům orgánů nadací a nadačních fondů),

- stanovením pravidel pro omezení výše nákladů na správu,

- definováním specifických podmínek pro zrušení a zánik nadací a nadačních fondů (likvidační zůstatek zůstává v neziskové sféře),

- $\quad$ stanovením podmínek pro audit účetní závěrky a zveřejňování výroční zprávy.

Tabulka 2: Srovnání podmínek pro činnost nadací a nadačních fondů před a po účinnosti zákona č. 227/1997 Sb., o nadacích a nadačních fondech

\begin{tabular}{|c|c|c|c|c|}
\hline \multirow[t]{2}{*}{ Kritérium } & \multirow{2}{*}{$\begin{array}{c}\text { Nadace podle } \\
\text { hospodářského zákoníku }\end{array}$} & \multirow{2}{*}{$\begin{array}{l}\text { Nadace podle } \\
\text { občanského zákoníku }\end{array}$} & \multicolumn{2}{|c|}{$\begin{array}{l}\text { Nadace a nadační fondy podle zákona } \\
\text { o nadacích a nadačních fondech }\end{array}$} \\
\hline & & & Nadace & Nadační fondy \\
\hline Právní úprava & $\begin{array}{c}\text { zákon č. 109/1964 Sb., } \\
\text { hospodářrský zákoník: } \\
\S 389 b\end{array}$ & $\begin{array}{c}\text { zákon č. 40/1964 Sb., } \\
\text { občanský zákoník: } \\
\text { § } 20 \mathrm{~b}-20 \mathrm{e} \\
\S 18 \text { až 20a }\end{array}$ & \multicolumn{2}{|c|}{$\begin{array}{c}\text { zákon č. 227/1997 Sb., o nadacích a } \\
\text { nadačních fondech }\end{array}$} \\
\hline $\begin{array}{l}\text { Charakteristika } \\
\text { obecně } \\
\text { prospěšného } \\
\text { cíle }\end{array}$ & $\begin{array}{l}\text { rozvoj duchovních } \\
\text { hodnot, ochrana lidských } \\
\text { práv nebo jiných } \\
\text { humanitních cílů, ochrana } \\
\text { a tvorba životního } \\
\text { prostředí i zachování } \\
\text { prrírodních hodnot }\end{array}$ & $\begin{array}{l}\text { rozvoj duchovních } \\
\text { hodnot, ochrana } \\
\text { lidských práv nebo } \\
\text { jiných humanitních cílů, } \\
\text { ochrana a tvorba } \\
\text { životního prostředí, } \\
\text { zachování přírodních } \\
\text { hodnot a ochrana } \\
\text { kulturních památek }\end{array}$ & \multicolumn{2}{|c|}{$\begin{array}{l}\text { rozvoj duchovních hodnot, ochrana } \\
\text { lidských práv nebo jiných humanitních } \\
\text { cílů, ochrana životního prostředí, } \\
\text { kulturních památek a tradic a rozvoj } \\
\text { vědy, vzdělání, tělovýchovy a sportu }\end{array}$} \\
\hline $\begin{array}{l}\text { Vznik, } \\
\text { registrace }\end{array}$ & okresní národní výbor & okresní úřad & \multicolumn{2}{|c|}{$\begin{array}{l}\text { zápisem do nadačního rejstř́íku, který } \\
\text { vede soud určený zvláštním zákonem }\end{array}$} \\
\hline Jmění & \multicolumn{2}{|c|}{ výše jmění není zákonem stanovena } & $\begin{array}{c}\text { hodnota jmění musí } \\
\text { být vyšśí než } \\
500 \text { 000,- Kč }\end{array}$ & \begin{tabular}{|l} 
výše jmění \\
není zákonem \\
stanovena
\end{tabular} \\
\hline Podnikání & \multicolumn{2}{|c|}{ v zákoně není zakázáno } & \multicolumn{2}{|c|}{ nesmí vlastním jménem podnikat } \\
\hline $\begin{array}{l}\text { Účast na } \\
\text { podnikání } \\
\text { jiných osob }\end{array}$ & \multicolumn{2}{|c|}{ v zákoně není zakázaná } & $\begin{array}{l}\text { mohou se podílet na } \\
\text { podnikání akciových } \\
\text { společností pouze do } \\
\text { určité míry }\end{array}$ & $\begin{array}{l}\text { nemohou se } \\
\text { podílet na } \\
\text { podnikání } \\
\text { jiných osob }\end{array}$ \\
\hline Statut & \multirow{3}{*}{$\begin{array}{l}\text { přiměřeně se použijí } \\
\text { ustanovení obecně } \\
\text { závazných předpisů } \\
\text { o občanských } \\
\text { sdruženích }\end{array}$} & $\begin{array}{l}\text { § 20c - jsou vyjmenovány } \\
\text { náležitosti statutu }\end{array}$ & \multicolumn{2}{|c|}{$\begin{array}{l}\text { § } 3 \text { - náležitosti nadační listiny } \\
\text { § } 4 \text { - náležitosti statutu }\end{array}$} \\
\hline $\begin{array}{l}\text { Poskytování } \\
\text { nadačních } \\
\text { příspěvků }\end{array}$ & & $\begin{array}{l}\text { zásady pro poskytování } \\
\text { nadačních př́ispěvků jsou } \\
\text { součástí statutu a jsou } \\
\text { v pravomoci orgánů } \\
\text { nadace }\end{array}$ & \multicolumn{2}{|c|}{$\begin{array}{l}\S 21 \text { (5) nelze poskytovat členům } \\
\text { orgánů a revizorovi }\end{array}$} \\
\hline $\begin{array}{l}\text { Zrušení } \\
\text { a zánik }\end{array}$ & & $\begin{array}{l}\S 20 \text { e a } \S 20 \text { a - na zrušení } \\
\text { a zánik nadace se použijí } \\
\text { přiměřeně ustanovení } \\
\text { obchodního zákoníku } \\
\text { o likvidaci obchodních } \\
\text { společností }\end{array}$ & \multicolumn{2}{|c|}{$\begin{array}{l}\text { § } 7 \text { odst. } 1 \text { - zánik ke dni výmazu } \\
\text { z nadačního rejstř́ku } \\
\S 7 \text { - zrušení } \\
\S 8 \text { - sloučení } \\
\S 9 \text { - likvidace } \\
\text { § } 9 \text { odst. } 4 \text { - likvidační zůstatek } \\
\text { přechází na: } \\
\text { - jinou nadaci nebo nadační fond } \\
\text { - } \quad \text { obec } \\
\text { - } \quad \text { stát }\end{array}$} \\
\hline
\end{tabular}

Zdroj: (Urbancová, Kryšková, 2008, s. 207), vlastní zpracování 
Následná aplikace zákona v praxi ukázala, že zákon má nedostatky a byl 8 krát novelizován. Podle $\S 3$ odst. 4 zákona o nadacích a nadačních fondech „Celková hodnota nadačního jmění nesmí být nižší než 500000 Kč a po dobu trvání nesmí klesnout pod tuto hranici. “ Zákonem č. 210/2002 Sb., byla doplněna ustanovení týkající se poklesu nadačního jmění pod stanovenou hodnotu ( $\$ 7$ odst. 3) a zákon byl rozšířen o následující řešení:

- $\quad$ nadace má lhůtu 1 rok od konce účetního období, v němž k poklesu došlo na doplnění nadačního jmění,

- $\quad$ správní rada nadace rozhodne o návrhu na vnitrostátní fúzi,

- $\quad$ soud na návrh zřizovatele, vykonavatele závěti, správní rady nebo osoby, která osvědčí právní zájem, nadaci zruší.

Podle $§ 23$ odst. 3 zákona č. 210/2002 Sb. byla povolena změna věcné skladby nadačního jmění, tj. peněžní prostředky na zvláštním účtu lze použít na nákup investičních nástrojů (nástroje peněžního trhu, dluhopisy, jejichž emitenty jsou státy nebo centrální banky, podílové listy otevřených podílových fondů) a nemovitostí.

\subsection{Právní úprava nadací a nadačních fondů podle nového občanského zákoníku} V částce 33 Sbírky zákonů byl zveřejněn zákon č. 89/2012 Sb., občanský zákoník. Tento nový občanský kodex mimo jiné ruší jednotlivé části zákona č. 227/1997 Sb., o nadacích a nadačních fondech s účinností od 1. 1. 2014. Podle přechodných ustanovení (\$ 3049) nového občanského zákoníku (NOZ) nadace a nadační fondy vzniklé podle dosavadních předpisů se považují za nadace a nadační fondy vzniklé podle nového občanského zákoníku.

NOZ obsahuje nově pojem veřejná prospěšnost a definuje $v \S 146$ veřejně prospěšnou právnickou osobu: „Veřejně prospěšná je právnická osoba, jejímž posláním je přispívat $v$ souladu se zakladatelským právním jednáním vlastní činností k dosahování obecného blaha, pokud na rozhodování právnické osoby maji podstatný vliv jen bezúhonné osoby, pokud nabyla majetek $z$ poctivých zdrojů a pokud hospodárně využivá své jmění $k$ veřejně prospěšnému účelu. “

NOZ pro nadace a nadační fondy používá společné označení fundace ( $\$ 303$ - 305): „Fundace je právnická osoba vytvořená majetkem vyčleněným k určitému účelu. Její činnost se váže na účel, $k$ němuž byla zř́zena. Fundace je ustavena zakladatelským právním jednáním nebo zákonem, $v$ nichž musí být určeny i jeji majetkové zajištěni a účel. Vnitřni poměry fundace upravuje její statut. “ NOZ v § 147 uvádí: „Veřejně prospěšná právnická osoba má právo na zápis statusu veřejné prospěšnosti do veřejného rejstříku, pokud splní podmínky stanovené jiným právním předpisem. “

Znamená to, že nadace nebo nadační fond má právo ne však povinnost zápisu statusu veřejné prospěšnosti a tedy v praxi budou vedle sebe existovat $\mathrm{N}$ a NF se statusem nebo bez statusu. Jen nadace a nadační fond, jejichž status veřejné prospěšnosti je zapsán ve veřejném rejstř́iku, má právo uvést ve svém názvu, že je veřejně prospěšná (viz $§ 150 \mathrm{NOZ}$ ). Status veřejné prospěšnosti je udělován na základě rozhodnutí určité autority (tak jako v některých evropských státech i v České republice z rozhodnutí soudu, v některých zemích o přidělení či odejmutí statusu veřejné prospěšnosti rozhodují finanční úřady). ${ }^{5}$

\footnotetext{
${ }^{5}$ http://obcanskyzakonik.justice.cz/tinymce-storage/files/zovp.pdf

Důvodová zpráva $k$ vládnímu návrhu zákona o statusu veřejné prospěšnosti
} 
Zákon č. 304/2013 Sb., o veřejných rejstř́ících právnických a fyzických osob reaguje na zrušení současného obchodního zákoníku a na ustanovení § 120 a 121 NOZ o veřejných rejstř́icích, která nabývají účinnosti od 1. 1. 2014. Zákon č. 304/2013 Sb., o veřejných rejstřících předpokládá vytvoření několika veřejných rejstříků právnických a fyzických osob (spolkový rejstřík, nadační rejstř́ík, rejstříku ústavů, rejstřík obecně prospěšných společností, rejstř́ík společenství vlastníkủ jednotek a obchodní rejstř́ik).

V NOZ je právní úprava nadací obsažena $v \$ 306$ - 393, nadačním fondům jsou vyhrazeny $\$ 394$ - 401. Lze jen konstatovat, že část týkající se nadací je v NOZ zpracována detailně. ${ }^{6}$ Je na škodu, že NOZ neřeší stejným způsobem i problematiku nadačních fondů. V NOZ není vymezena vedlejší činnost nadačních fondů, nejsou uvedeny podmínky pro ověřování účetní závěrky nadačního fondu auditorem, jsou opomenuty náležitosti výroční zprávy, podmínky pro její zveřejnění, popř́ípadě chybí i věta typu: „Pro nadační fondy platí § 341 až $\S 373$ tohoto zákona obdobně. Srovnání právní úpravy a podmínek pro činnost nadací i nadačních fondů podle vybraných kritérií podle zákona o nadacích a nadačních fondech a podle nového občanského zákoníku je obsaženo v tabulce 3.

V souvislosti se zněním $§ 147 \mathrm{NOZ}$ je nutno zmínit, že tímto jiným právním předpisem, je vládní návrh zákona o statusu veřejné prospěšnosti (sněmovní tisk č. 989), ${ }^{7}$ který obsahuje další podstatné podmínky a důležité skutečnosti, týkající se veřejně prospěšných právnických osob a tedy i nadací a nadačních fondů a který k datu 31. 12. 2013 nebyl schválen. Nová koncepce právní úpravy od 1. 1. 2014 měla představovat určitou regulaci statusu veřejné prospěšnosti, který je získán v důsledku vykonávání veřejně prospěšné činnosti (poslání organizace a dosahování obecného blaha) nikoliv pouze nabytím určité právní formy. $\mathrm{V}$ neschváleném vládním návrhu zákona o statusu veřejné pospěšnosti jsou upraveny podmínky, za kterých má veřejně prospěšná právnická osoba ${ }^{8}$ právo na zápis statusu veřejné prospěšnosti do veřejného rejstř́ku. Tento zákon mimo jiné definuje znaky veřejné prospěšnosti, které musí veřejně prospěšná právnická osoba splňovat pro získání statusu, upravuje práva a povinnosti veřejně prospěšné právnické osoby se statusem, uvádí neúplný seznam veřejně prospěšných činností, stanovuje podmínky pro odnětí statusu a výmazu statusu, definuje pojmy bezúhonnost a neslučitelnost funkcí. Podkladem pro zápis statusu do veřejného rejstř́íku je rozhodnutí soudu o právu na zápis statusu veřejně prospěšné právnické osoby do veřejného rejstř́iku (jestliže veřejně prospěšná právnická osoba doloží soudu naplnění znaků veřejné prospěšnosti podle $§ 2$ až 4 neschváleného zákona).

\section{2 Účetnictví nadací a nadačních fondů}

Nadace a nadační fondy jsou právnickými osobami, jsou účetními jednotkami a plně se řídí zákonem č. 563/1991 Sb., o účetnictví ve znění pozdějších předpisů. Podle $§ 9$ současného znění zákona o účetnictví vedou účetní jednotky účetnictví $\mathbf{v}$ plném rozsahu, pouze vyjmenované účetní jednotky mohou vést účetnictví ve zjednodušeném rozsahu. Před 1. 1. 2004 účetní jednotky účtovaly v soustavě podvojného účetnictví a účetní jednotky uvedené v § 9 mohly účtovat $v$ soustavě jednoduchého účetnictví. Tak jak se měnila legislativa

\footnotetext{
${ }^{6} \mathrm{http}: / /$ www.elger.cz/index.php?page=nase-reseni

Přizpưsobení nadací a nadačních fondi̊ novému občanskému zákoníku

http://obcanskyzakonik.justice.cz/infocentrum/informacni-brozury/

Prưvodce Občanským zákoníkem pro nadace a nadační fondy

${ }^{7} \mathrm{http} / / /$ obcanskyzakonik.justice.cz/tinymce-storage/files/zovp.pdf

Vládni návrh zákona o statusu veřejné prospěšnosti

${ }^{8}$ Zákon č. 586/1992, o daních z př́ijmů (§ 17a) od 1. 1. 2014 používá pojem veřejně prospěšný poplatník.
} 
nadací a později i nadačních fondů, tak docházelo i ke změnám v požadavcích na vedení účetnictví nadací a nadačních fondů. Nadace vzniklé podle hospodářského a občanského zákoníku mohly účtovat o majetku a závazcích, o svých př́jmech a výdajích v soustavě jednoduchého účetnictví, od roku 1998 nadace musely účtovat v soustavě podvojného účetnictví. Nadační fondy při splnění určitých podmínek mohly účtovat v soustavě jednoduchého účetnictví do konce roku 2004 (viz přechodná ustanovení zákona o účetnictví), nebo mohly začít vést účetnictví ve zjednodušeném rozsahu (nadační fondy nemají povinnost vést účetnictví v plném rozsahu).

Tabulka 3: Srovnání podmínek pro činnost nadací a nadačních fondů podle zákona o nadacích a nadačních fondech a nového občanského zákoníku

\begin{tabular}{|c|c|c|}
\hline Kritérium & $\begin{array}{c}\text { Dosavadní právní úprava } \\
\text { Zákon č. 227/1997 Sb., o nadacích a } \\
\text { nadačních fondech }\end{array}$ & $\begin{array}{c}\text { Právní úprava po 1. 1. } 2014 \\
\text { Zákon č. 89/2012 Sb., občanský zákoník }\end{array}$ \\
\hline $\begin{array}{l}\text { Poslání, } \\
\text { cíl, účel, } \\
\text { hlavní } \\
\text { činnost }\end{array}$ & $\begin{array}{l}\text { Nadace a nadační fondy - účelová } \\
\text { sdružení majetku pro dosahování } \\
\text { obecně prospěšných cílů. Obecně } \\
\text { prospěšným cílem je zejména rozvoj } \\
\text { duchovních hodnot, ochrana lidských } \\
\text { práv nebo jiných humanitárních hodnot, } \\
\text { ochrana prírodního prostředí, kulturních } \\
\text { památek a tradic a rozvoj vědy, vzdělání, } \\
\text { tělovýchovy a sportu. }\end{array}$ & $\begin{array}{l}\text { Zakladatel zakládá nadaci k trvalé službě } \\
\text { společensky nebo hospodářsky užitečnému účelu. } \\
\text { Účel nadace může být veřejné prospěšný, spočívá- } \\
\text { li v podpoře obecného blaha, i dobročinný, } \\
\text { spočívá-li v podpoře určitého okruhu osob určených } \\
\text { jednotlivě či jinak. } \\
\text { Zakladatel zakládá nadační fond k účelu } \\
\text { užitečnému společensky nebo hospodářsky. }\end{array}$ \\
\hline Vznik & den zápisu do rejstř́ku & den zápisu do veřejného rejstř́íku \\
\hline Zánik & den výmazu z rejstř́ku & den výmazu z veřejného rejstř́ku \\
\hline Založení & $\begin{array}{l}\text { písemná smlouva, zakládací listina, } \\
\text { závět' }\end{array}$ & $\begin{array}{l}\text { nadační listina (zakládací listina, pořízení pro } \\
\text { př́pad smrti) }\end{array}$ \\
\hline Nadace & nadační jmění vyšší než 500000 Kč & $\begin{array}{l}\text { před vznikem souhrnná výše vkladů alespoň } \\
\mathbf{5 0 0} 000 \text { Kč, } \\
\text { nadační jistina (vklady do nadace + nadační dary) } \\
\text { nadační kapitál (peněžní vyjádření nadační } \\
\text { jistiny), zapisuje se do veřejného rejstř́ku }\end{array}$ \\
\hline Podnikání & $\begin{array}{l}\text { nadace a nadační fondy nesmí } \\
\text { vlastním jménem podnikat }\end{array}$ & $\begin{array}{l}\text { nadace může podnikat, pokud podnikání } \\
\text { představuje vedlejší činnost }\end{array}$ \\
\hline $\begin{array}{l}\text { Nadační } \\
\text { příspěvky }\end{array}$ & $\begin{array}{l}\text { nelze poskytovat členům orgánů a } \\
\text { revizorovi }\end{array}$ & $\begin{array}{l}\text { nadace nesmí poskytnout nadační příspěvek osobě, } \\
\text { která je členem orgánu, zaměstnancem ani osobě } \\
\text { jim blízké }\end{array}$ \\
\hline $\begin{array}{l}\text { Náklady } \\
\text { na správu }\end{array}$ & $\begin{array}{l}\text { omezení nákladů na správu je součástí } \\
\text { statutu, vedou se odděleně od nadačních } \\
\text { příspěvků }\end{array}$ & $\begin{array}{l}\text { nadace mají povnnost vést náklady na správu } \\
\text { odděleně od nadačních příspěvků }\end{array}$ \\
\hline $\begin{array}{l}\text { Audit } \\
\text { účetní } \\
\text { závěrky }\end{array}$ & $\begin{array}{l}\text { nadace mají povinnost auditu vždy, } \\
\text { nadační fond podléhají auditu, jestliže } \\
\text { hodnota nákladů, nebo výnosů nebo } \\
\text { majetku je vyšší než } 3 \text { mil. Kč }\end{array}$ & $\begin{array}{l}\text { nadace mají povinnost auditu účetní závěrky, } \\
\text { jestliže nadační kapitál nebo obrat za účetní období } \\
\text { je vyšśí než } \mathbf{5} \text { mil. Kč nebo se rozhoduje o zvýšení } \\
\text { nebo snížení nadačního kapitálu }\end{array}$ \\
\hline $\begin{array}{l}\text { Náležitosti } \\
\text { výroční } \\
\text { zprávy }\end{array}$ & $\begin{array}{l}\text { jsou definovány shodně pro } \mathrm{N} \text { a NF, } \\
\text { povinnost uložení výroční zprávy u } \\
\text { rejstř́íkového soudu platí pro N i NF }\end{array}$ & $\begin{array}{l}\text { jsou definovány pouze pro nadace, povinnost } \\
\text { uložení výroční zprávy ve veřejném rejstř́ku je } \\
\text { stanovena pouze pro nadace }\end{array}$ \\
\hline $\begin{array}{l}\text { Dozorčí } \\
\text { rada }\end{array}$ & $\begin{array}{l}\text { nadace zřizuje dozorčí radu, jestliže } \\
\text { nadační jmění je vyšší než } 5 \text { mil. Kč, } \\
\text { nadační fond zřizuje dozorčí radu, } \\
\text { jestliže hodnota majetku NF je vyšší } \\
\text { než } 5 \text { mil. Kč }\end{array}$ & $\begin{array}{l}\text { nadace zřizuje dozorčí radu, jestliže nadační } \\
\text { kapitál je vyšší než } 5 \text { mil. Kč }\end{array}$ \\
\hline $\begin{array}{l}\text { Likvidační } \\
\text { zůstatek }\end{array}$ & $\begin{array}{l}\text { likvidační zůstatek přechází na jinou } \\
\text { nadaci či nadační fond, obec nebo stát }\end{array}$ & $\begin{array}{l}\text { likvidační zůstatek nadace může přejít r } \\
\text { nadaci, obec, kraj nebo stát }\end{array}$ \\
\hline
\end{tabular}

Zdroj: vlastní zpracování 
Nadace sestavují účetní závěrku v plném rozsahu, nadační fondy mohou sestavovat účetní závěrku ve zjednodušeném rozsahu (pokud nejsou povinny mít účetní závěrku ověřenou auditorem, do výkazů se zapisují zpravidla zůstatky skupinových účtů). Účetní závěrku nadací a nadačních fondů tvoří rozvaha, výkaz zisku a ztráty a příloha. Nadační fondy, které $\mathrm{v}$ roce 2003 mohly účtovat $\mathrm{v}$ soustavě jednoduchého účetnictví, postupovaly podle vyhlášky č. 507/2002 Sb., kterou se provádějí některá ustanovení zákona č. 563/1991 Sb., o účetnictví, ve znění pozdějších předpisů, pro účetní jednotky, účtující v soustavě jednoduchého účetnictví, sestavovaly přehled o majetku a závazcích a přehled o př́ijmech a výdajích. Podle $\S 31$ odst. 2 písm. a) zákona o účetnictví účetní jednotky uschovávají účetní závěrku a výroční zprávu po dobu 10 let následujících po roce, kterého se týkají. Účetní jednotky předkládají účetní závěrku příslušnému finančnímu orgánu, pokud podávají daňové přiznání (viz $§ 38 \mathrm{~m}$ odst. 8 zákona o daních z př́ijmů, od 1. $1.2014 \S 38 \mathrm{mb}$ ).

Výroční zprávu nadace a nadační fondy vypracovávaly a zveřejňovaly v souladu s $\$ \mathbf{2 5}$ až $\mathbf{2 6}$ zákona o nadacích a nadačních fondech. Nadace a nadační fondy sestavovaly výroční zprávu nejpozději do šesti měsíců po skončení hodnoceného období (kalendářního roku). Nadace nebo nadační fondy uložily výroční zprávu u rejstř́íkového soudu. V nadační listině nebo statutu nadace nebo nadačního fondu mohl být stanoven další způsob zveřejnění výroční zprávy. Výroční zpráva nadací a nadačních fondů obsahovala zejména:

- přehled majetku a závazků,

- přehled prrijatých nadačních darů,

- přehled o osobách, jimž byly poskytnuty nadační příspěvky,

- zhodnocení, zda nadace nebo nadační fond při hospodaření dodržuje pravidlo stanovené pro omezení nákladů souvisejících s jejich správou,

- zhodnocení základních údajů obsažených v roční účetní závěrce a výrok auditora.

Od 1. 1. 2003 se nadace a nadační fondy při vedení účetnictví řídí vyhláškou č. 504/2002 Sb., kterou se provádějí některá ustanovení zákona č. 563/1991 Sb., o účetnictví, ve znění pozdějších předpisů, pro účetní jednotky, u kterých hlavním předmětem činnosti není podnikání, pokud účtují v soustavě podvojného účetnictví a Českými účetními standardy pro účetní jednotky, které účtují podle vyhlášky č. 504/2002 Sb., ve znění pozdějších předpisů (České účetní standardy pro účetní jednotky, u kterých hlavním předmětem činnosti není podnikání, účinnost od 1. 1. 2004). Přehled podmínek pro vedení účetnictví a audit účetní závěrky nadací a nadačních fondů je uveden v tabulce 4 . Z této tabulky je zřejmé, že podmínky kladené na vedení účetnictví nadací a nadačních fondů, jejich účetní výkazy a ověřování účetní závěrky auditorem se v jednotlivých etapách vývoje jejich legislativy precizovaly a zpř́isňovaly (přechod z účtování v peněžním deníku v soustavě jednoduchého účetnictví do soustavy podvojného účetnictví). Pokud ale zahrneme do srovnání i změny, které přináší nový občanský zákoník, dochází k určitému zmírnění nároků - pouze nadace budou mít povinnost auditu účetní závěrky, jestliže nadační kapitál nebo obrat za účetní období je vyšší než 5 mil. Kč nebo se rozhoduje o zvýšení nebo snížení nadačního kapitálu. Praxe ukáže, zda toto „uvolnění“ bude ku prospěchu (snížení nákladů na odměnu auditora) či naopak povede k poklesu důvěry veřejnosti, donátorů a uživatelů informací $\mathrm{z}$ účetní závěrky ve věrný a poctivý obraz předmětu účetnictví a finanční situace účetní jednotky.

Podle $\S 66$ písm. c) zákona č. 304/2013 Sb., o veřejných rejstřících právnických a fyzických osob sbírka listin obsahuje?: „výroční zprávy, rádné, mimořádné a konsolidované účetní

\footnotetext{
${ }^{9}$ Důležité ve vztahu k účetnictví mělo být ustanovení $§ 9$ odst. 3 neschváleného návrhu zákona o statusu veřejné prospěšnosti: „Přesahuje-li výše obratu právnické osoby se statusem v uplynulém účetním období 5 milionů Kč, podléhá účetní závěrka vždy ověreni auditorem. "Veřejně prospěšná právnická osoba se statusem by měla navíc
} 
závěrky, nejsou-li součástí výroční zprávy, stanoví-li povinnost jejich uložení do sbírky listin zákon upravujicí účetnictví osob a vyžaduje-li jejich vyhotovení jiný zákon, návrh rozdělení zisku nebo vypořádání ztráty a jejich konečnou podobu, nejsou-li součástí účetní závěrky, a zprávu auditora o ověrení účetní závěrky..."

Tabulka 4: Účetnictví a podmínky pro audit účetní závěrky nadací a nadačních fondů

\begin{tabular}{|c|c|c|c|c|}
\hline \multirow[t]{2}{*}{ Kritérium } & \multirow{2}{*}{$\begin{array}{l}\text { Nadace podle } \\
\text { hospodářského } \\
\text { zákoníku }\end{array}$} & \multirow{2}{*}{$\begin{array}{l}\text { Nadace podle } \\
\text { občanského } \\
\text { zákoníku } \\
\end{array}$} & \multicolumn{2}{|c|}{$\begin{array}{l}\text { Nadace podle zákona o nadacích a } \\
\text { nadačních fondech }\end{array}$} \\
\hline & & & Nadace & Nadační fondy \\
\hline $\begin{array}{l}\text { Právní úprava } \\
\text { účetnictví }\end{array}$ & $\begin{array}{l}\text { Zákon, } \\
\text { vyhlášky FMF }\end{array}$ & \multicolumn{3}{|c|}{$\begin{array}{l}\text { Zákon č. 563/1991 Sb., o účetnictví, ve znění pozdějších předpisů } \\
\text { (účinnost od } 1.1 .1992)^{11}\end{array}$} \\
\hline $\begin{array}{l}\text { Rozsah vedení } \\
\text { účetnictví } \\
\text { (od roku } 2004, \\
\text { plný nebo } \\
\text { zjednodušený } \\
\text { rozsah vedení } \\
\text { účetnictví) }\end{array}$ & \multicolumn{2}{|c|}{$\begin{array}{l}\text { S účinností zákona o účetnictví je } \\
\text { stanovena hranice př́imů pro účtování } \\
\text { v soustavě jednoduchého a podvojného } \\
\text { účetnictví: } \\
\text { \$9 zákona o účetnictví - nadace } \\
\text { účtují v soustavě jednoduchého } \\
\text { účetnictví, pokud nepodnikají nebo } \\
\text { jejich př́ijmy nedosáhly v předchozím } \\
\text { roce výše } 3 \text { mil. Kč }\end{array}$} & $\begin{array}{l}\text { od } 1.1 .1998 \\
\text { účtují v soustavě } \\
\text { podvojného } \\
\text { účetnictví } \\
\text { od } 1.1 .2004 \\
\text { vedou účetnictví } \\
\text { v plném } \\
\text { rozsahu }\end{array}$ & $\begin{array}{l}\text { v období } 1998-2001 \\
\text { účtují v soustavě } \\
\text { jednoduchého } \\
\text { účetnictví, pokud jejich } \\
\text { příjmy jsou nižší než } 3 \\
\text { mil. Kč (od } 1.1 .2002 \\
\text { př́ijmy nižší než } 6 \text { mil.) } \\
\text { v roce } 2004 \text { mohou } \\
\text { některé NF účtovat ještě } \\
\text { v soustavě } \\
\text { jednoduchého účetnictví } \\
\text { od } 1.1 .2004 \text { mohou } \\
\text { nadační fondy vést } \\
\text { účetnictví ve } \\
\text { zjednodušeném rozsahu }\end{array}$ \\
\hline \multirow{2}{*}{$\begin{array}{l}\text { Audit účetní } \\
\text { závěrky }\end{array}$} & \multirow[t]{2}{*}{ není povinný } & \multirow[t]{2}{*}{ není povinný } & \multicolumn{2}{|c|}{ § 24 odst. 2 zákona o $\mathrm{N}$ a NF } \\
\hline & & & $\begin{array}{l}\text { účetní závěrka } \\
\text { musí být } \\
\text { ověřena } \\
\text { auditorem vždy }\end{array}$ & $\begin{array}{l}\text { účetní závěrka musí být } \\
\text { ověřena auditorem, } \\
\text { jestliže úhrn nákladů, } \\
\text { nebo úhrn výnosů nebo } \\
\text { majetku je vyšší než } 3 \\
\text { mil. Kč }\end{array}$ \\
\hline
\end{tabular}

Zdroj: (Urbancová, 2008, s. 208) aktualizované vlastní zpracování

Audit účetní závěrky (podle zákona č. 93/2009 Sb., o auditorech) je zaměřen na ověření, zda informace uvedené $v$ účetní závěrce podávají ve smyslu platných předpisů věrný a poctivý obraz předmětu účetnictví a finanční situace účetní jednotky. Výsledkem práce nezávislého auditora je Zpráva auditora o ověření účetní závěrky. Platnost Auditorské směrnice č. 55 - Audit nevýdělečných organizací byla zrušena, v současné době auditoři při auditu nadací a nadačních fondů postupují podle Metodické pomůcky pro audit nevýdělečných organizací $^{12}$, přičemž aplikace této pomůcky není závazná. Tato pomůcka představuje

povinnost uložit výroční zprávu do sbírky listin veřejného rejstř́ku (tj. podmínky pro audit a uložení do sbírky listin by platily nejen pro nadace, ale i pro nadační fondy).

\footnotetext{
${ }^{10}$ Zákon č. 21/1971 Sb., o jednotné soustavě sociálně ekonomických informací, vyhláška FMF č. 154/1971,

o účetnictví

${ }^{11}$ Zákonem č. 563/1991 Sb., došlo mimo jiné ke zrušení nařízení vlády ČSSR č. 136/1989 Sb., o informační soustavě organizací, vyhlášky Federálního ministerstva financí č. 155/1971 Sb., o inventarizacích hospodářských prostředků a vyhlášky Federálního ministerstva financí č. 23/1990 Sb., o účetnictví.

${ }^{12}$ http://www.kacr.cz/file/755/A3-2012-Priloha-Vychodiska-NNO.pdf
} 
materiál (metodický návod), který obsahuje: právní normy, kterými se konkrétní nevýdělečné organizace řídí a specifika auditu těchto právnických osob.

V souvislosti s NOZ nedošlo k 1. 1. 2014 ke změně ustanovení § 9 Rozsah vedení účetnictví a znamená to, že $v$ souladu se zákonem o účetnictví nadace a nadační fondy pokračují ve vedení účetnictví, tj. nadace vedou účetnictví v plném rozsahu a nadační fondy mohou vést účetnictví ve zjednodušeném rozsahu.

\section{Závěr}

Př́spěvek byl zpracován na základě analýzy a porovnání stávající a předchozí právní úpravy a také s využitím aktuálních publikací v elektronické podobě včetně stanovisek Komise pro aplikaci nové civilní legislativy pracující při Ministerstvu spravedlnosti. ${ }^{13}$

\section{Na základě provedené deskripce, analýzy a komparace lze konstatovat, že:}

- činnost nadací a nadačních fondů do roku 2013 upravoval jeden zákon č. 227/1997 Sb., o nadacích a nadačních fondech, po 1. 1. 2014 to jsou dvě základní právní normy (NOZ a zákon o veřejných rejstř́cích právnických a fyzických osob),

- část týkající se nadací je v NOZ zpracována detailně, NOZ neřeší stejným způsobem problematiku nadačních fondů,

- zákon o statusu veřejné prospěšnosti nebyl schválen, přesto NOZ (§ 147) a zákon o veřejných rejstř́ících právnických a fyzických osob ( $\$ 7$ písm. i) obsahuje ustanovení o zápisu statusu veřejné prospěšnosti do veřejného rejstř́ku a zákon o daních z př́ijmů po 1. 1. 2014 používá pojem veřejně prospěšný poplatník,

- nadace a nadační fondy vedou v současné době „podvojné“ účetnictví, nadace vedou účetnictví v plném rozsahu, nadační fondy mohou vést účetnictví ve zjednodušeném rozsahu,

- podle zákona č. 227/1997 Sb., měly nadace povinnost ověření účetní závěrky auditorem vždy a nadační fondy tehdy, jestliže hodnota nákladů, nebo výnosů nebo majetku je vyšší než 3 mil. Kč,

- po 1. 1. 2014 nadace budou mít povinnost auditu účetní závěrky, jestliže nadační kapitál nebo obrat za účetní období je vyšší než 5 mil. Kč nebo se rozhoduje o zvýšení nebo snížení nadačního kapitálu (NOZ tuto povinnost nadačním fondům neukládá a zákon o statusu veřejné prospěšnosti nebyl schválen),

- podle zákona č. 227/1997 Sb., byly definovány shodně pro nadace a nadační fondy podmínky, ze kterých vyplývá povinnost uložení výroční zprávy do sbírky listin u rejstříkového soudu; po 1. 1. 2014 NOZ stanoví povinnost uložení výroční zprávy ve veřejném rejstř́íku pouze pro nadace,

- u nadací přetrvává povinnost členit náklady a výnosy na veřejně prospěšné činnosti, ostatní činnosti a dále na svoji správu a dále vykazovat ve výroční zprávě nadační dary a nadační př́spěvky (u nadačních fondů tato povinnost není v NOZ uvedena),

- při rozhodování potencionálních zakladatelů při volbě, zda založit nadaci nebo nadační fond, bude i nadále rozhodující podmínka vkladu ve výši 500000 Kč při založení nadace,

- podle zákona o daních z př́ijmů nadace a nadační fondy při splnění zákonem předepsaných podmínek patří mezi veřejně prospěšné poplatníky,

\footnotetext{
Východiska k poskytováni auditorských služeb u nestátních nevýdělečných organizací. Mimořádná př́iloha časopisu Auditor č. 3/2012.

13 http://obcanskyzakonik.justice.cz/infocentrum/informacni-brozury/

Nástin řě̌ení některých výkladových problémů právní úpravy nadačních fondi̊
} 
- $\quad \mathrm{v}$ důsledku neschválení zákona o statusu veřejné prospěšnosti nedošlo $\mathrm{k}$ prosazení nové koncepce právní úpravy od 1. 1. 2014, která měla přispět ke změně v posuzování neziskových organizací ne podle nabytí určité právní formy, ale podle skutečně vykonávané veřejně prospěšné činnosti.

Autorky se domnívají, že negativním rysem nové právní úpravy je absence ustanovení týkajících se auditu účetní závěrky, náležitostí výroční zprávy a podnikání nadačních fondů a nezastávají názor, že část uvedená v NOZ v Pooddílu 2 Nadace platí i pro nadační fondy uvedené v Pododdílu 3Nadační fond.

\section{Literatura}

[1] ELGER, M., 2014. Přizpưsobení nadací a nadačních fondů novému občanskému zákoníku [online]. [vid. 26. května 2014]. Dostupné z: http://www.elger.cz/index.php?page=nase-reseni

[2] FRIŠTENSKÁ, H. a kol., 2013. Průvodce Občanským zákoníkem pro nadace a nadační fondy [online]. [vid. 26. května 2014 ]. Dostupné z: http://obcanskyzakonik.justice.cz/infocentrum/informacni-brozury/

[3] HURDÍK, J., 1994. Problémy nadačního práva. Brno: Masarykova univerzita. ISBN 80210-1015-0.

[4] Nástin řešení některých výkladových problémů právní úpravy nadačních fondů [online]. [vid. 26. května 2014]. Dostupné http://obcanskyzakonik.justice.cz/infocentrum/informacni-brozury/

[5] TELEC, I., 1994. Univerzitni a fakultni nadace: aplikace mimorozpočtového zdroje financováni vysokých škol a vysokoškolského studia $v$ soudobých podmínkách. Brno: Masarykova univerzita. ISBN 80-210-1049-5.

[6] URBANCOVÁ, A., 2000. Právní úprava, účetnictví a daně obecně prospěšných společností, nadací a nadačních fondů. Doktorská disertační práce. Ostrava: Vysoká škola báňská - Technická univerzita Ostrava, Ekonomická fakulta.

[7] URBANCOVÁ, A. a Š. KRYŠKOVÁ, 2008. Účetnictví nevýdělečných organizací A. Ostrava: VŠB - Technická univerzita Ostrava. ISBN 978-80-248-1801-6.

[8] Vládní návrh zákona o statusu veřejné prospěšnosti [online]. [vid. 26. května 2014]. Dostupné z: http://obcanskyzakonik.justice.cz/tinymce-storage/files/zovp.pdf

[9] Východiska k poskytování auditorských služeb u nestátních nevýdělečných organizací [online]. [vid. 26. května 2014]. Dostupné z: http://www.kacr.cz/file/755/A3-2012Priloha-Vychodiska-NNO.pdf

[10] Zákon č. 40/1964 Sb., občanský zákoník, ve znění pozdějších předpisů

[11] Zákon č. 109/1964 Sb., hospodářský zákoník, ve znění pozdějších předpisů

[12] Zákon č. 103/1990 Sb., kterým se mění a doplňuje hospodářský zákoník

[13] Zákon č. 563/1991 Sb., o účetnictví, ve znění pozdějších předpisů

[14] Zákon č. 586/1992 Sb., o daních z příjmů, ve znění pozdějších předpisů

[15] Zákon č. 227/1997 Sb., o nadacích a nadačních fondech, ve znění pozdějších předpisů

[16] Zákon č. 89/2012 Sb., občanský zákoník

[17] Zákon č. 304/2013 Sb., o veřejných rejstřících právnických a fyzických osob 